\title{
The compliment as a speech act in Russian: A lexical-pragmatic study
}

\author{
EWA KOMOROWSKA \\ ANNA OHRIMOVICH
}

Received 1.02.2018, accepted 29.06.2018.

\begin{abstract}
The aim of the paper is to identify the linguistic exponents of Russian compliments. The examples which will be analyzed come from contemporary Russian.

We will consider direct and indirect compliments, paying attention to such phenomena as presupposition and implicature as well as to the pragmatic functions of utterances. An analysis of communication strategies will allow us to present the specific features and role of compliments in linguistic communication in Russia.
\end{abstract}

\section{Keywords}

compliment, praise, Russian, speech act, pragmatics, presupposition, implicature

\section{Komplement jako akt mowy w języku rosyjskim: Badanie leksykalno-pragmatyczne}

Celem artykułu jest zbadanie językowych eksponentów rosyjskich komplementów. Przykłady, które będą analizowane, pochodzą ze współczesnego języka rosyjskiego. 
Rozważymy bezpośrednie i pośrednie komplementy, zwracając uwage na takie zjawiska, jak presupozycja i implikatura, a także na pragmatyczne funkcje wypowiedzi. Analiza strategii komunikacyjnych pozwoli nam przedstawić charakterystyczne cechy komplementów i ich rolę w komunikacji językowej w Rosji.

\section{Słowa kluczowe}

komplement, pochwała, język rosyjski, akt mowy, pragmatyka, presupozycja, implikatura

\section{The compliment as a speech act}

The aim of this paper is to present the compliment as a speech act (Austin 1962, Searle 1969) in the modern Russian language.

Compliments - as a sociolinguistic phenomenon - have been of great interest to researchers, especially those investigating the English language. English compliment have been examined by, inter alia, Robert Herbert (1991), Janet Holmes (1986, 1988), Nessa Wolfson (1984), Nessa Wolfson and Joan Manes (1980), Barbara Lewandowska-Tomaszczyk (1989) and Angela Creese (1991).

Russian compliments have been investigated by, inter alia, Mariâ Bezâeva (2002) and Nataliâ Formanovskaâ (1994, 2007). However, in pragmalinguistic studies, researchers deal with the issue of compliments mainly while discussing other speech acts, such as praising. Taking into consideration the previous studies, publications concerning this subject are not numerous. As far as we know, no monograph on Russian compliments has been released so far. The considerations presented in this paper are supposed to be an introduction to a more detailed study of the compliment as a speech act in contemporary Russian. 
In this paper, the speech act of compliment is defined as follows: it is a language action that is performed in order to influence the recipient and make a positive impression. It is the action of, for example, expressing the opinion that the recipient of the compliment looks attractive, he/she has acted or performed well. In other words, the speech act of compliment, due to the positive evaluation of the recipient, is to affect him/her positively and provoke a favourable reaction.

The speech act of compliment is usually connected with evaluating physical characteristics and qualities, appearance, style and outlook, as well as personality traits, peculiar qualities in somebody's character, abilities and skills. We consider the compliment being semantically close to the praise as a speech act. But we still see the difference between these two. As mentioned, compliments refer to a person's physical and mental features, while praises are connected with actions being taken, e.g.

(1) Ольга, ты очень мудрая девушка. (compliment) 'Olga, you are a very wise girl.'

(2) Ольга, ты очень мудро поступила в этой ситуаиии. (praise) 'Olga, you did very wisely in this situation.'

It should be noted that a praise can have an official character and can appear in the written form. We acknowledge though that the difference between complimenting and praising in Russian is sometimes very subtle. In the present study, our attention will be focused on the speech act of compliment, and the speech act of praise will be considered in another study.

Taking into account the issue of truth, two basic types of compliments can be distinguished: one of them occurs when the sender pays a compliment sincerely, according to his/her beliefs; in the other case, the sender, opposite to his/her opinion, pays compliments for a certain purpose. For instance, this takes place when the sender appeals to his/her supervisor to gain favour, or to his/her friend in order to create a pleasant atmosphere. Here we deal with so called white 
lies. ${ }^{1}$ For example, a person visits his friend who has recently been ill; the recovered girl looks bad; however, he does not want to hurt her and avoids this with the help of a white lie, paying the following compliment: You look amazing!

\section{The structure of the compliment as a speech act}

Although compliments are frequently expressed with constructions containing evaluative lexemes, it is difficult to clearly state what the universal structure of compliments is in Russian. However, certain basic structures can be identified and illustrated with selected examples. ${ }^{2}$

\subsection{Adverbs}

The group of adverbs expressing positive evaluation is quite large in Russian, ranging from quite formal expressions to informal or slang words. The use of the latter is not only considerable but also constantly increasing. It should be noted that their English equivalents used in conversations are not adverbs, but adjectives.

(3) Сногсшибательно! 'Knocking!'

(4) Потрясающе! 'Shocking!'

(5) Изумительно! 'Astonishing!'

(6) Восхитительно! 'Fascinating!'

(7) Прекрасно! 'Beautiful!'

(8) Чудесно! 'Wonderful!'

(9) Бесподобно! 'Extraordinary!'

(10) Блестяще! 'Great!'

(11) Великолепно! 'Great!'

1 The research on the phenomenon of lying in verbal communication was carried out by Jolanta Antas in her book O kłamstwie $i$ kłamaniu IOn Lies and Lying] (2008). The author discusses the following communication strategies: partial judgments, false conclusions, misleading silence, secrets, halftruth, compliments, white lies and nonverbal lies.

2 Some examples are excerpted from a dictionary of Russian speech etiquette (Bakalaj 2007). 
(12) Здорово! 'Neat!', 'Sound!'

(13) Необыкновенно! 'Extraordinary!'

(14) Henлохо! 'Not bad!'

(15) Heотразимо! 'Charming!'

(16) Обворожительно! 'Charming!'

(17) Ослепительно! 'Brilliant!'

(18) Отлично! 'Excellent!'

(19) Отменно! 'Excellent!'

(20) Шикарно! 'Elegant!'

(21) Потрясно! 'Shocking!'

(22) Классно! 'Classy!'

(23) Клево! 'Fine!', 'Great!' (slang)

\subsection{Nouns}

The use of evaluative nouns may be enforced by the use of exclamatory particles such as $H y, н y$, npocmo, and interjec-

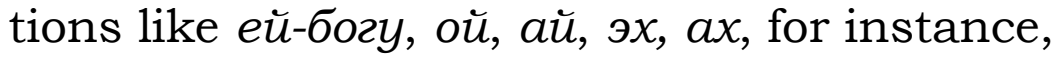

(24) Aнгел! 'Angel!'

(25) Ангелок! 'Angel!' (dim.)

(26) Ангелочек! 'Angel!' (dim.)

(27) Bocmopz! 'Admiration!'

(28) Загляденье! 'Wonder!'

(29) Kracc! 'Class!'

(30) Просто куколка! 'Simply a doll (dim.)!' (compliment paid to an attractively looking girl)

(31) Omnad! 'Fall-out!' (slang)

(32) Yydo! 'Wonder!'

(33) Пять с плюсом! 'Five plus!' (a school mark)

(34) Wuк! 'Elegance!'

(35) Ну, блеск! 'What shine (i.e. excellence)!'

(36) Ax, богиня! 'What a goddess!'

(37) Верх совершенства, ей-богу! 'Top of excellence, I swear!'

(38) Эx, краса да и только! 'What a beauty (and only beauty)!'

(39) Oй, красавеи мужиина! 'What a handsome man!'

(40) Ай, светлая голова! 'What an intellect!' 


\subsection{Constructions}

Let us now present the most common constructions used in compliments.

\section{- Construction umo $3 a+$ noun:}

Unlike its English equivalent "what $a+$ noun", in Russian constructions of this type may sound quite unnatural in everyday informal conversations, but they are widely used in literature.

(41) Что за прелесть! 'What a wonder!'

(42) Hy umo за чyдo! 'What a wonder!'

- Noun + possessive pronoun:

(43) Kрасавииа моя! 'My beautiful (one)!'

(44) Милашка моя! 'My nice (one)!'

(45) Сокровище ты мое! 'My treasure!'

\section{- Nominal phrase:}

(46) Золотая голова! '(What an) intellect!'

(47) Большое сердие (у вас)! '(You have a) good heart!'

(48) Золотое сердие (у вас)! '(You have a) golden heart!'

\section{- Simple sentence with a nominal/adjectival predicate:}

(49) Вы ангел! 'You're an angel!

(50) Bu-uдear! 'You're an ideal!'

(51) Bu сама доброта. 'You're only goodness!'

(52) Вы великолепны! 'You're great!'

(53) Вы очень внимательны / так добры / любезны! 'You're very kind / so good / nice!'

(54) Я в восторге / в восхищении! 'I'm full of admiration!' 


\section{- Simple sentence with a compound nominal predicate:}

(55) Bы реджий мужиина. 'You're an exceptional man.'

(56) Вы умный человек. 'You're a wise person.'

(57) Bu само очарование. 'You're charming.'

- Modal constructions:

(58) Обалдеть можно! 'One may go silly!'

(59) С ума сойти можно! 'One may go mad!'

- Verb in the indicative mood:

(60) Saкaчaeubcr! 'Sit down because you'll fall!'

(61) Залюбуешься! 'You'll be full of admiration!'

(62) Мучше не бывает / не придумаешь! 'You'll come up with nothing better!'

\section{- Sentence with a verb in the imperative mood:}

(63) Оставайтесь такой же молодой / красивой. 'Always be so young / beautiful.'

(64) Примите мое восхищение. 'Accept my admiration.'

(65) Разрешите выразить мое восхииение. 'Let me express my admiration.'

(66) Защибисъ! 'Hit yourself!' (slang)

\section{- Sentence with a verb in the subjunctive mood:}

(67) Никогда не дал бы Вам столько лет. 'I would never say that you are so many years old.'

(68) Будъ я моложе, сразу бы женился на этой красавиие. 'If I were younger, I would marry this beauty.' 


\section{- Personal pronouns obl 'you' (pl.) and mbl 'you' (sing.) in the nominative case + (adverb) + verb:}

(69) Bъь всё хорошеeme. 'You're becoming more beautiful.'

(70) Ть молодо выглядишь. 'You look young.'

(71) Вы ничуть не изменились. 'You haven't changed at all.'

(72) (Тъ) cимпатично въглядишь. 'You look nice.'

(73) Bы сегодня выглядите намного лучше. 'Today you look much better.'

(74) Tь хорошо выглядишь. 'You look good.'

In the last example, the evaluative adverb xopoun 'good' may be substituted with other adverbs of the same nature, depending on the sender's intention to emotionally strengthen the utterance. These could be the following adverbs (whose English equivalents are adjectives): сногсшибательно 'knocking', потрясаюше 'shocking', изумительно 'astonishing', восхитительно 'fascinating', прекрасно 'beautiful', чудесно 'wonderful', бесподобно 'extraordinary' and великолепно 'great'. The mentioned adverbs are quite frequently accompanied by the modifying adverb npocmo 'simply':

(75) Tbь выглядишь просто бесподобно! 'You simply look extraordinary!'

It is worth mentioning that the insertion of the adverb npocmo causes the change of word order, e.g.

(76) Ты замечательно выглядишь. 'You look great.' (lit. you great look)

(77) Ты выглядишь просто замечательно. 'You look simply great.' (lit. you look simply great)

Adding the modifying adverb and moving the adverbial phrase to the end of the sentence causes the strengthening of the illocutionary force of the second compliment (example 77). 


\section{- Personal pronouns ob 'you' (pl.) and mbl 'you' (sing.)} in the genitive/dative case + verb + object:

(78) Вам идет это платье / стрижка / ивет. 'This dress / haircut / colour suits you.'

(79) Тебе не дашь твоих лет. 'No one will say you're your age.'

(80) Вас красит эта прическа. "This hairdo makes you beautiful.'

(81) Вас молодит эта стрижка. 'This haircut makes you look younger.'

(82) Тебе к лииу это платье / этот образ. 'This dress / image suits you.'

\section{- Personal pronoun $\boldsymbol{r}$ ' $I$ ' in the nominative case + verb} + object:

(83) Я восхииаюсь Вашим талантом. 'I admire your talent.'

(84) Я не могу на тебя налюбоваться. 'I cannot stop enjoying your looks.'

(85) Я не устаю восторгаться вами. 'I do not stop admiring you.'

\section{- Constructions with кaא 'how':}

(86) Как вы добры / хороши / красивы! 'How good / handsome / beautiful you are!'

(87) Oŭ, кaк xopoun! 'Oh, how good!'

(88) Как вы молодо / хорошо / великолепно выглядите. 'Hоw young / good / great you look.'

(89) Как mы выросла / похорошела! 'How you have grown / become beautiful!'

(90) Как вы расивели! 'How you have blossomed!'

(91) Kак вы прекрасно таниуете! 'How splendidly you can dance!'

\section{- Constructions with какой/ кaкar 'what':}

(92) Какая прелесть / краля / краса / красавииа / красота / лапонька / лапочк / милашка! 'What a wonder / nice girl 
/ beauty / beautiful girl/woman / beauty / hand (dim.) / beloved (one)!'

(93) Какой молодеи / талант / красавеи / умнииа! 'What a nice young man / talent / handsome man / clever person!'

(94) Какая чудесная ульбка / красивая кофточка! 'What a wonderful smile!'

(95) Какая красивая кофрточка! 'What a beautiful blouse!'

(96) Какая вы красивая! 'How beautiful you are!'

(97) Какой вы добрый / милый / любезный! 'How good / nice / kind you are!'

\section{- Rhetorical questions:}

This pattern can be realized in different ways. Quite a common type is a question with negation:

(98) Разве она не прекрасна? 'Isn't she beautiful?'

(99) Ну не талант? 'Isn't it a talent?'

Besides, sentences with a modal component are frequently used to perform the action of complimenting:

(100) Можно ли быть прекраснее? 'Is it possible to be more beautiful?'

(101) Как можно бьло родиться таким красивьм? 'Was it possible to be born more beautiful?'

\section{- Interjections:}

Being a language means to express emotions and different sentiments, interjections are frequently accompanied by nonverbal means of compliment expression.

(102) Bo! (accompanied by the gesture "thumb up") 'Yes!', 'Wow!'

(103) Bom эmo da! 'This is it!'

(104) Haдо же! 'Who could think so?'

(105) Ничего себе! 'Not bad!' 
(106) O-o-o! 'Oh!'

(107) Ozo! 'Oh!'

(108) C yмa coùmu! 'Go mad!'

(109) Hy вы nocnompume! 'Look!'

Indeed, facial expressions, gestures and the posture can signalize and strengthen the language action of complimenting. For example, raising eyebrows as if one is surprised together with evaluative lexemes may express complimenting. A similar effect is achieved by approving gestures, such as keeping the thumb up or connecting the thumb and forefinger in a circle and holding the other fingers straight.

\section{Orientation}

The functions of the speech act of compliment may be divided according to its orientation. Thus, compliments may be addressed to the interlocutor, the third person through the interlocutor and oneself. The first type of compliments is the most common in Russian conversations. With the second type, positive evaluation reaches not only the third person but also the interlocutor who hears this compliment. For example, when a mother receives a compliment on her daughter's beauty or intelligence, the direct addressee of the compliment is the daughter. However, the mother may also take it as a compliment for herself, as the daughter takes after her in appearance, has inherited intelligence or her achievements are the result of the mother's enormous efforts to give her child excellent education. The third type of compliments, those targeted at oneself, are usually of humorous nature and are expressed indirectly, so that the speaker does not sound too proud of him/herself. However, the speaker may openly boast on purpose to look humorous and create a friendly atmosphere. Selected examples of all three types of compliments are presented below. 


\section{- Compliments addressed to the other person:}

(110) Вероника, ть очень красивая! 'Veronica, you are very beautiful!'

(111) Хорошо выглядишь, удачно подобрала это платье! 'You look good, you have successfully picked up the dress!'

(112) Тебе идёm этот uвет! 'This colour suits you!'

(113) Haташа, ты прекрасная хозяйка! 'Natasha, you are a wonderful hostess!'

\section{- Compliments addressed to the third person through the interlocutor:}

(114) Какая у Вас красивая дочь! 'What a beautiful daughter you have!'

(115) Знаешь, я очень рада за твою оленьку. Они с Димой очень хорошая пара. Наверно, никак не можешь нарадоваться своим зятем? 'You know, I am so happy for your Olga. She and Dima make such a great couple. Seems like you can't be happier with your son-in-law.'

(116) Что бы ни говорили, а сосед у тебя просто замечательный. 'Whatever they say, but you have the most wonderful neighbour.'

\section{- Compliments addressed to oneself:}

(117) Я самая обаятельная и привлекательная. 'I am the most charming and attractive.'

(118) У моего мужа хороший вкус, иначе как бы он выбрал такую жену? 'My husband has good taste, otherwise how could he be able to choose a wife like me?'

(119) Мучшего мужчину на свете пришлось родить самой (о своём сыне). 'I happened to give birth to the best man in the world' (about one's own son). 


\section{Pragmatic aspects of the functioning of the speech act of compliment}

The use of compliments becomes a kind of complementary action that enhances other language actions.

\subsection{Phatic speech acts}

With phatic speech acts, such as greetings and farewells, a compliment fulfills the function of appreciation, creating a good image and especially maintaining a pleasant atmosphere. These acts are at the border of complements and politeness formulas. The veracity of the utterance does not occupy a crucial role here; its objective is to create a positive atmosphere.

Selected examples:

(120) Доброе утро, Тамара Александровна! Как вы прекрасно выглядите! Как загорели-mo! 'Good morning, Tamara! You look wonderful! How tanned you are!'

(121) Пока! Оставайся всегда такой жке красивой! 'Вуе! Stay so beautiful forever!'

\subsection{Nonbinding directive $\operatorname{acts}^{3}$}

With directive speech acts, the double intention of the utterance may appear: in the acts of requesting, offering and

\footnotetext{
${ }^{3}$ In the study Pragmatyka dyrektywnych aktów mowy $w$ jezyku polskim. Pragmatik von Aufforderungshandlungen im Deutschen, Polnischen und Russischen. Прагматика побудительнх речевых актов в немеиком, польском и русском языках, directive speech acts are divided into two basic groups - binding and nonbinding directive speech acts. The criterion of the division is based on the pragmatic value of the speech acts towards the necessity or absence of necessity to accomplish a suggested action. With the nonbinding speech acts, the receiver may but does not have to perform the proposed action, and the denial does not lead to any undesirable consequences. The denial may only affect further relations. With binding speech acts, however, failure to perform a suggested action causes certain sanctions (Komorowska et al. 2008: 27).
} 
advising, a compliment serves an additional argumentative function, which intensifies the directive action.

Selected examples:

(122) Надежна Ивановна, у Вас случайно не будет немного caxapy? Я забыла купить, а Вы всегда такая запасливая... 'Nadezhda Ivanovna, don't you happen to have some sugar? I forgot to buy some, and you are, as far as I know, always so provident...'

(123) Может, поедем вместе в Испанию? Ты превосходно говоришь nо-испански! 'Maybe we should go to Spain together? You speak Spanish very well!'

(124) Я бы тебе посоветовала забыть его. Он того не стоит. ты ведъ такая умная и красивая женшина! 'I would advise you to forget him. He's not worth it. You are such an intelligent and beautiful woman!'

\subsection{Binding directive acts}

As opposed to the speech acts mentioned above, in binding directive acts, such as demanding, ordering and commanding, compliments carry out a different function of mitigating the utterance. That is why in the situation when disobedience may lead to undesirable consequences, the receiver understands the importance of performing the action; however, he/she may feel the speaker's support and approval.

Selected examples:

(125) Я требую приложить максимум усилий, чтобы выцгать эту игру. Ведь наша команда лучшая! 'I demand the best efforts to win the game. After all, our team is the best!'

(126) Павел, проект должен быть окончен до среды. Кто, как не Вы, может подойти ответственно к этому делy? 'Paul, the project should be done by Wednesday. Who else but you can deal with this issue responsibly?'

(127) Приказываю Вам немедленно взять себя в руки! Насколько я помню, вашему самообладанию всегда 
можно бъло позавидовать. 'I order you to immediately pull yourself together! As far as I remember, one could always envy you for your self-control.'

\subsection{Acts of disapproval and threatening}

Similarly to the above-mentioned binding directive acts, the use of compliments with the acts of disapproval and threatening causes weakening of the action force. It is worth mentioning that with this type of speech acts, compliments usually appear at the end of the utterance. This position of compliments may be caused by the observation of the nonverbal behaviour of the interlocutor that makes the sender mitigate the utterance when he/she notices, for example, the redness of the interlocutor's face, shaking hands and anxiety in the eyes.

Selected examples:

(128) Не могу поверить, ито ты так некрасиво поступил с Николаем. Что на тебя нашло? Ты ведъ самый верный дpyг на свете! 'I can't believe that you acted so badly with Nikolai. What got into you? You are the most loyal friend in the world!'

(129) Если немедленно не уберёшь у себя в комнате, то никогда из неё не выйдешъ! Ты ведъ умная девочка и сама понимаешь, как важно поддерживать порядок. 'If you don't clean up your room, you are never going to leave it! You are a smart girl and understand how important it is to keep it clean.'

\section{The importance of context}

Speech act theory opened a new research perspective for language study as it shifted the focus from the structural analysis of an utterance to the context in which it is uttered. ${ }^{4}$

4 As Ludwig Wittgenstein (1953) states, a word gains its meaning through its use. 
This approach shows that besides grammatical competence, one should also acquire the knowledge of conventions and communication rules. Thus, developing this awareness is crucial, for breaking the above-mentioned conventions may lead to the failure of intercultural communication. Now and again in a communicative situation, the disruption in understanding the sender's intentions may occur, for example:

(130) А: Какой красивый ребёнок!

В: Говорят, весь в меня.

A: Нет, совсем не похож.

'A: What a beautiful baby!

B: They say he takes after me.

A: No, he doesn't look like you at all.'

In example (130), the mother acknowledges a compliment to her son. Undoubtedly, such compliments please every mother. However, the woman may also seek to hear nice words about her as well. That is why she gives a hint. The recipient does not understand her intention of receiving a compliment, and this causes failure to achieve the expected purpose. Let us consider another example.

(131) Это платье тебя стройнит! 'This dress makes you look slim!'

Example (131) implies that the compliment refers to a temporary quality of the recipient, but normally her look is worse. Thus, this compliment has a double meaning and it cannot affect the hearer as positively as may be intended.

\section{Conclusion}

As the conducted analysis shows, the compliment as a speech act is accomplished with various language actions, starting from greetings and farewells, through nonbinding directive speech acts such as requests and offers, to binding speech 
acts like orders and commands, or the speech act of threatening. The realization of the speech act of compliment is implemented due to various lexical units and grammatical constructions. It is worth emphasizing that the speech act of compliment fulfills an approbatory function, becoming a means of manipulation and language games.

The considerations presented in this paper are - as has already been signalled - an introduction to a more detailed study of the compliment as a speech act in contemporary Russian.

\section{Acknowledgements}

We would like to thank Zofia Stanulewicz and Danuta Stanulewicz for translating the examples from Russian into English.

\section{References}

Antas, Jolanta (2008). O kłamstwie i kłamaniu. Kraków: Towarzystwo Autorów i Wydawców Prac Naukowych UNIVERSITAS.

Austin, John L. (1962). How to Do Things with Words. Oxford: Oxford University Press.

Bezâeva, Mariâ G. (2002). Semantika kommunikativnogo urovnâ zvuŝego âzyka. Moskva Izdatel'stvo: Moskovskogo Universiteta [Безяева Мария Г. (2002). Семантика коммуникативного уровня звущего языка. Москва: Издательство Московского Университета].

Bakalaj, Anatolij Georgievič (2007). Slovar' russkogo rečevogo ètiketa. Moskva: Astrel' [Бакалай, Анатолий Георгиевич (2007). Словарь русского речевого этикета. Москва: Астрель].

Creese, Angela (1991). "Speech act variation in British and American English". Penns Working Papers in Educational Linguistics 7/2: 37-58.

Formanovskaâ, Nataliâ Ivanovna (1994). "Pragmatika pobuždeniâ i logika âzyka". Russkij âzyk za rubežom 5-6: 34-40 [Формановская, Наталия Ивановна (1994). “Прагматика 
побуждения и могика языка". Русский язык за рубежом 5-6: 34-40].

Formanovskaâ, Nataliâ Ivanovna (2007). Rečevoe vzaimodejstvie: kommunikaciâ i pragmatika. Mockva: Ikar [Формановская, Наталия Ивановна (2007). Речевое взаимодействие: коммуникация и прагматика. Москва: Икар].

Herbert, Robert K. (1991). "The sociology of compliment work: An ethnocontrastive study of Polish and English". Multilingua 10/4: 381-402.

Holmes, Janet (1986). "Compliments and compliment responses in New Zealand English". Anthropological Linguistics 28/4: 485508.

Holmes, Janet (1988). "Paying compliments: A sex-preferential politeness strategy". Journal of Pragmatics 12: 445-465.

Komorowska, Ewa, Urszula Kantorczyk, I. Р. Lysakova [И. П.

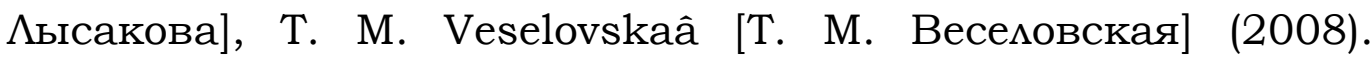
Pragmatyka dyrektywnych aktów mowy w jezyku polskim / Pragmatik von Aufforderungshandlungen im Deutschen, Polnischen und Russischen / Pragmatika pobuditel'nyh rečevyh aktov $v$ nemeckom, pol'skom i russkom âzykah [Прагматикa побудительных речевых актов в немеиком, польском u русском языках]. Szczecin - Rostock: Volumina.pl Daniel Krzanowski.

Leech, Geoffrey N. (1983). Principles of Pragmatics. New York: Longman Group Limited.

Lewandowska-Tomaszczyk, Barbara (1989). "Praising and complimenting”. In: Wiesław Oleksy (ed.). Contrastive Pragmatics. Amsterdam: Benjamins, 73-100.

Searle, John (1969). Speech Acts: An Essay in the Philosophy of Language. London: Cambridge University Press.

Wolfson, Nessa (1984). "Pretty is as pretty does: A speech act view of sex roles". Applied Linguistics 5/3: 236-244.

Wittgenstein, Ludwig (1972 [1953]). Dociekania filozoficzne. Trans. Bogusław Wolniewicz. Warszawa: Państwowe Wydawnictwo Naukowe.

Wolfson, Nessa, Joan Manes (1980). "The compliment as a social strategy". Papers in Linguistics: International Journal of Human Communication 13/3: 391-410. 
Ewa Komorowska

ORCID iD: 0000-0002-8089-4440

Instytut Filologii Słowiańskiej

Uniwersytet Szczeciński

al. Piastów 40 B

70-065 Szczecin

ekomorowska@post.pl

Anna Ohrimovich

Independent Scholar 